\title{
THE SUBJECT CLASSIFICATION OF REPORTED CASES
}

\author{
Hon. Charles C. Lester, State Reporter of Neav York Miscel- \\ laneous Cases.
}

To Dr. Johnson has been attributed the statement: "Knowledge is of two kinds; we know a subject ourselves, or we know where we can find information upon it."

If $\mathrm{Dr}$. Johnson was right in designating knowledge of a subject and knowledge of where to find information upon it, "two kinds of knowledge," he might have gone further and stated that one of these kinds of knowledge, as a general rule, must precede the other and is a necessary condition to its acquisition. I am quite convinced that lawyers do not realize what practical difficulties stand in the way of the beginner seeking knowledge of the sources of information upon legal subjects.

And I am led by my own experience to believe that adequate attention is not always given by instructors to imparting that most useful knowledge of the sources of information and the ways by which they may be reached.

Samuel Warren, an English lawyer of the last century, better known to the general public as the writer of the tales, "Ten Thousand a Year," and "The Diary of a London Physician," wrote also an admirable little book entitled, "Introduction to Law Studies," which, many years ago, when I began the study of my profession, my father placed in my hands with the advice that I should read it. In this book, Mr. Warren, remarking upon the broadness of the field of legal learning and the multiplicity of topics, asks: "What memory can pretend to a practical familiarity with a thousandth part of it?" He then remarks that a facility of reference will, in a great measure, compensate for this necessary deficiency in a practical familiarity with the broad field of legal learning, and proceeds to offer some practical suggestions toward the attainment of so desirable an object. Among other things, he-says: "Let, therefore" (speaking of the student of law), "one of his earliest objects be to familiarize himself with the leading heads of law, so that, on reading over any statement of facts he may at least know in what quarter to look for information as, Principal and Agent, Stoppage in Transitu, 
Tender, Set-off, Agreements, Bills of Exchange, Death of Parties, etc., as enumerated in the table of contents in any of the leading works of reference.

The author then proceeds to speak in terms of praise of Comyn's Digest and declares that the editor of Winne's Eunomus justly describes it as the best book of reference. He urges upon the student a close study of this digest, and advises him to ascertain the author's system and method of distribution, though he admits one little impediment, in the Lord Chief Baron's constant adoption of obsolete words for the headings of particular articles. "Who would think, for instance," he inquires, "of hunting for information concerning tithes under the head of 'Dismes'; goods and chattels under 'Biens'; deeds under 'Fait'; highways under 'Chimin'; for the signification and construction of particular words and phrases under 'Parols'?' This obstacle, however, the author declares, "may be soon surmounted by a little perseverence."

At this point I may properly invite your attention to this digest of the Chief Baron of His Majesty's Court of Exchequer. It is most interesting in many particulars and not the least so in being, as I take it, one of the progenitors of our modern digests. It contains not only the adjudications of the English courts, but the Statutes and references to the treatises of the elementary writers of an earlier day, which were esteemed authoritative at the beginning of the last century. It was not published until after the author's death. It was written in law French, except for the citations of the statutes, which were in English, and was translated into English before it was published. But the topics or titles were left in the original tongue; for it was found that their translation into English would change their order, if an alphabetical arrangement were adhered to, as the author had planned, and this was deemed a disadvantage. This was one of the first works of the kind, if I am not mistaken, in which an alphabetical arrangement was adopted, and that arrangement has been adhered to by digesters ever since. If the topics themselves are examined, it will be found that many of them are identical with those in the digests of the present day, though many have become obsolete, owing to radical changes in legal procedure; and many new topics have found their place in modern digests with the wonderful growth in social and commercial activity during the last hundred years. But we shall find recog- 
nized as topics for treatment a long list of particular crimes such as Arson, Burglary, Murder, and the like; and a like list of particular occupations, such as Apothecary, Carrier, Factor, Innkeeper, and other familiar groups of topics; and shall find, in short, no fundamental difference from the system of classification in vogue at the present day.

In their preface, the editors say, "The general plan of this digest is, that the Author lays down Principles or Positions of law and illustrates them by instances which he supports by authorities, etc." Unless I am mistaken, this is fundamentally inaccurate. The author does not lay down principles, but topics that are not at all principles, but represent rather some concrete subject to which divers principles are applicable. Legal principles are, for the most part, without distingtishing names and for that reason are incapable of treatment in this manner. Instead of finding cases illustrating a given principle grouped together, they will be found scattered broadcast and placed under topics that represent the different matters to which they have been applied. The student seeking a legal principle is likely to stand aghast after his first attempt to find it in a digest. Of the hundreds of topics in the digest he will easily count upon his fingers all that can in any sense be said to stand, themselves, for definite legal principles.

It is said that legal principles are few and simple. I am bound to add that they are likewise elusive, without names, difficult of statement in the abstract, and often difficult of recognition when applied. I suppose they are to be found embodied in legal maxims and therein stated in their most intelligible form. The first task of the student seeking to find the law in the digest is to realize that he must find the principle, if at all, in its application.

Chief Baron Comyn died in 1740 and his digest was published in sections, the first making its appearance about 1762 . His work was, doubtless, a great one and entitled to all the commendation it received at the hands of the versatile and talented author of the law studies to which $I$ have referred.

Another work of similar character that made its appearance about the same time ought, however, to be mentioned in this connection for, unless I am mistaken, it has been more extensively used by the American bar than Comyn's Digest. I refer to Bacon's Abridgement. This work is said to have been a compilation from the writings of the late Chief Baron Gilbert by Matthew Bacon, an English lawyer, and made its appearance in 1736, twenty-six years earlier than the digest of Chief Baron 
Comyn. The seventh English editon was published in 1831 , and an American edition was published as early as 1809 .

Since the appearance of Bacon's Abridgement and the digest of Chief Baron Comyn, more than a century has passed away. A cataclysm of reports and digests has swept into the broad field of legal learning. Not all the digests are entitled to the favorable expressions of the editor of Wynne's Eunomus toward Comyn's Digest; and, though the particular obstacle to an understanding of the plan and arrangement of topics in that work, to which Mr. Warren called attention, will not be experienced in an effort to become familiar with the digests of to-day, other diffculties quite as great will probably be encountered. There has been a great increase in the number of the topics separately treated and with which the student is compelled to familiarize himself if he is to acquire that facility of reference which may supplement his incomplete knowledge of the law. Moreover, there has been a considerable diversity among digesters in their nomenclature, and their subdivision of topics; so that a person accustomed to one digest will encounter difficulty when called upon to use another. These differences, however, are in details; and what $I$ have to say in respect to the arrangement and classification of cases and the subdivision of topics will, for the most part, be found applicable to all digests alike.

These remarks, it should be noted, will be found applicable to digest systems rather than to the treatises of elementary writers. Many such treatises, bearing titles identical with topics appearing in the digests, may be found in all considerable libraries. In their scope and the arrangement of their material such treatises will usually be found to differ from the like topics of the digest. Often, I had almost said usually, the elementary treatise is broader in scope than the topic of the digest, the tendency of digesters being to multiply subjects by stubdivision. A legal subject, treated by an elementary writer in a broad and comprehensive way, will be found in the digest in such narrow and contracted form as to be almost unrecognizable. The subject of negligence is a good illustration of my meaning. Its treatment by elementary writers will make the treatment of the subject by digesters a puzzle to the uninitiated. The digest article is almost startling, in its insignificance and at once suggests the inquiry, What has become of the matter that ought to be found here? The answer is that it has been distributed through the digest among various topics, under which cases are to be found bearing upon 
the rights and obligations of those engaged in particular occupations or standing in particular relations to each other or to the public. Cases involving this subject will be found under Carriers, Druggists, Inn-keepers, Master and Servant, Principal and Agent, and many other topics. Students should, therefore, remember that, when they turn from elementary treatises to the digest to find the cases involving the subjects in which they have become interested through their orderly, methodical and logical treatment at the hands of the elementary writers, they are likely to find much of the matter they seek under other heads and to find the subject whose broad treatment has engaged them shrunk to a semblance of its just proportions. This is a matter of no little importance, and a proper understanding of it will lead to a great saving of time when an investigation of the sources of authority is undertaken.

Although there are many treatises upon legal subjects that will well repay the student for their careful perusal, when the serious work of the profession is undertaken, recourse must be had to the reports of adjudicated cases, for it is these that speak with ultimate authority.

Blackstone, in his introductory chapters, in explaining how the customs and maxims constituting the common law were to become known, says (Vol. I, p. 73): "And thus much for the first ground and chief cornerstone of the laws of England, which is general, immemorial custom, or common law, from time to time declared in the decisions of the courts of justice; which decisions are preserved among our public records, explained in our reports, and digested for general use in the authoritative writings of the venerable sages of the law."

Our own Chancellor Kent has said (Vol. I, p. 473): "The reports of judicial decisions contain the most certain evidence, and the most authoritative and precise application of the rules of the common law. Adjudicated cases become precedents for future cases resting upon analogous facts, and brought within the same reason; and the diligence of counsel and the labor of judges are constantly required, in the study of the reports, in order to understand accurately their import and the principles they establish. . But to obtain a competent knowledge of the common law in all its branches has now become a very serious undertaking and it requires steady and lasting perseverence in consequence of the number of books which beset and incumber the path of the student." 
But if Kent was moved to complain of the multitude of books that beset the student's pathway in his day, what can we say of their number now? An estimate, made about the time Kent's Commentaries were written, stated their number as follows:

English Reports ..................364 volumes

Digested Indexes ................. 33 volumes

Text Books ..................... 184 volumes

Digests and Abridgements ..........6 67 volumes

Total ....................648 volumes

Besides, American reports, treatises and digests amounting to 200 volumes more.

To-day there are extant more than one thousand volumes of reported decisions of the courts of the State of New York, to say nothing of digests and treatises, too numerous to mention. If to these we add the reports of the other States, the Federal Reports and the enormously augmented number of the English reports, I am tempted to exclaim, in the language of St. John: "I suppose that even the world itself could not contain the books."

But the books are here. The world does contain them and the patient work of digesters, following in the footsteps of the Chief Baron of his Majesty's Court of Exchequer, has gone far to make them serviceable to the student and to the practitioner. We can avail ourselves of the results of the labors of the digesters by understanding their methods and the systems of classification they employ.

When we speak of the system of classification upon which digests are founded we do not intend, of course, the arrangement of topics. As to this there is little to be said. The arrangement in all cligests is alphabetical. In this there is no opportunity for the application of logical methods. Its supreme convenience is the foundation of its universal use.

The system of digesters is the method of arranging under topics titles or subjects the reported decisions. It is the arrangement of cases under titles and not the arrangement of the titles or topics themselves. This is the system to which I invite your consideration. It has not been devised by a single mind, but represents a growth, and is so completely shaped in the legal literature of many states and foreign countries that it is beyond the power of any individual to mold anew. We shall have occasion to criticise it and find fault with it, but we cannot greatly change it. In situdying it we shall be like the student of geography, com- 
pelled to take the oceans and continents as we find them. We cannot smooth out coast lines nor reduce altitudes nor plant new lands in the midst of oceans where we think they ought to exist. And we shall find disputed boundaries and regions claimed by different sovereignties and we shall be troubled about unnatural subdivisions of territory and unreasonable extensions of authority.

If one starts out with the theory that the titles or topics employed by legal writers and digesters are or ought to be particular legal principles, he will be disconcerted when he discovers how far afield such a theory leads him; for, as I have already observed, cases of this kind are rare and, upon reflection, the reason is obvious. If legal principles, by the genius of some juridical writer. had received names and thereby become vitalized as entities, they would have assumed places in the family of topics; but, though many of them are capable of definite statement and many are embodied in well-known legal maxims, for the want of a name they have never received recognition as subjects, but have been classified and discussed in connection with various topics. To illustrate: Estoppel in pais, which is the principle of frequent application that, where one has asserted a fact to influence another's conduct and it has been acted upon, he will not thereafter be heard to deny it to the other's prejudice, occupies a recognized place as a subject in encyclopedias and digests of law. The same is true of "Subrogation" and "Contribution" and a few other like topics. But the well-known principle that where two or more persons equally at fault embark in an illegal enterprise the law will not interfere between them, but will leave them as it finds them, which is succinctly and picturesquely stated in the legal maxim: "In pari delicto potior est conditio defendentis," having never received a name, has no place in the family of legal subjects and will be found discussed in connection with various matters to which it may apply.

Therefore, one of the first things to be noted in considering the topics to which cases are referred by digesters and indexers is that these topics cannot with strict propriety be called legal subjects. They are not coterminous with definite legal principles. They are concrete rather than abstract and usually comprehend the application of a multitude of legal principles to a group of human affairs more or less closely connected through some particular relation between individuals growing out of contracts, or domestic, political or public institutions. We shall find, accordingly, the various occupations, professions and employments of men treated 
as topics. We shall find among them the domestic relations and many of the more artificial relations of a contractual nature. We shall find the rights and prerogatives of sovereignty, the rights and privileges of persons, and each particular field of individual activity in which the State may interpose its control or prohibition, represented as topics, each involving such legal principles as may apply thereto. We shall find many subjects referable to legal remedies as contradistinguished from legal rights.

We cannot fail to be impressed with the great number of recognized topics. In the principal digest of the reports of the State of New York we find, after aisregarding all that are merely definitions of words and cross references, and enumerating only such as comprehend actual adjudications of the courts, between five and six hundred such topics. We may, however, find solace in the reflection that out of this great number, 287 may be considered, estimating them by the space devoted to them, as minor topics; some of them requiring but a single paragraph for their treatment and none of them more than a single page. Upon the same basis, 154 other topics may be estimated as of average importance, only, leaving but 69 which can justly be considered as topics of major importance.

Of the topics I have mentioned, considerably more than onehalf may be referred, generally, to substantive law and the remainder to practice, though many comprehend questions both of law and practice. Of the 527 topics treated in Abbott's Encyclopedic Digest of New York Reports, I have referred 368, tentatively, to substantive law and 159 to practice.

Turning our attention to the 368 topics referred to substantive law, let us see what relations, if any, exist among them and whether they are capable of logical classification.

In examining these 368 topics we shall soon discover that many of them consist of particular crimes which have a definite and distinguishing name, such as Arson, Burglary, Forgery and the like; while under the head of Criminal Law will be grouped all minor offenses not possessing the dignity of a name and the multitudes of statutory offenses generally involving no moral turpitude and only mala prohibita. To this class of topics may be added a few, closely related, such as Forfeiture and Penalties, and we shall have a group of 55 topics closely related to each other and easily separable from the remaining $3^{1} 3$ and constituting more than oneseventh of all. 
To the foregoing may be added a group of torts not amounting to crimes, wrongs against persons and not against the State, for which the law affords civil remedies and which affect contractual rights and the enjoyment of property. Twenty such topics will be found.

Pursuing further the plan of grouping related topics, we find a considerable number treating of particular professions, trades, employments or occupations. They are named without any uniform system of nomenclature, some by the name applied to persons engaged in the particular occupation, as Druggists and Factors, others by the names of the occupations themselves, as Banking and Peddling, and others by the name of the thing in respect to which the business is prosecuted, as Wharves. Each of these topics embraces the rights, duties and obligations of persons engaged in the particular occupation and those for whom the services they render are performed. There are other topics not easily distinguishable from these except by. the fact that they relate to occupations of such a character and affect so closely the public welfare that the State has, in the exercise of the police power, interposed to regulate them. They include what are known as "Public Utilities." There are in all 39 such topics.

Another and a very large and important group of kindred topics consists of contracts in general and particular contracts, under which logically fall topics that have to do with contracts, such as "Consideration," and contractual relations, such as "Master and Servant" and "Principal and Surety." In this group may be placed, naturally and without violence, at least 57 topics.

In like manner, 44 topics may be referred to Real Property; three to Waters and Water Courses; ten to Personal Property; four to Intangible Property Rights, such as "Good Will"; five to the Acquisition and Loss of Property; five to Trusts and Trustees; four to the Estates of Deceased Persons; and five topics may be referred to Debtor and Creditor.

We now come to a group of topics relating to Personal Rights, Relations and Disabilities, as distinguished from property rights, and including the Domestic Relations, to which 20 topics are referable.

Next we find a group of topics relating to the rights, duties and obligations growing out of the association of individuals and their incorporation and the regulation by the State of the formation of associations and corporations and their activities, in all 25 in number. 
Another group of topics, startling for the paucity of its numbers, is that comprehending principles affecting property and personal rights and contracts. In all the hundreds of legal topics, but four of this kind appear; and I am not sure that I have not done violence to some of them in my efforts to make up even that small number.

Having reachecl this point, it is easy to dispose of the remaining topics. Eleven are different Systems of Law, such as Admiralty, Colonial Law and Common Law. Nineteen represent Sovereign Powers, Prerogatives and Franchises; 38 represent the objects of Government Control, such as Public Charities, Education, Forests, Fish and Game, matters involving questions of Public Morals, Health and Safety, Transportation, Highways, Public Utilities, Commerce and Standards of Measurements, Weight and Time. Nineteen represent different Public Officers; seven Municipal Corporations and matters connected therewith.

- This groups all the recognized topics found in digests, though cruclely and in a manner to which many exceptions may justly be taken, but accurately enough to give a general view of the entire field.

I have attempted to arrange these topics in a logical and orderly manner uncler general heads. This $I$ have done in the following manner:

Owing to the multiplicity of topics, it would be profitless for me to set forth this table at length ; but $\mathrm{I}$ may, perhaps, indicate in a general way what $I$ have attempted. I have referred this great number of topics to twenty-four heads, viz:

Ist-Systems of Law, to which I have referred eleven topics.

2nd-Sovereign Powers, Prerogatives and Franchises, to which I have referred nineteen topics.

3rd-Crimes and Their Punishment, to which I have referred fifty-five topics.

4th-Public Charities, to which I have referred two topics.

5th-Public Education, to which I have referred three topics.

6th-Forests, Fish and Game, to which I have referred four topics.

7th-Public Morals, Health and Safety, - to which I have referred nineteen topics.

8th-Commerce, Transportation and Public Utilities, to which I have referred nineteen topics. 
gth-Public Officers, to which I have referred eighteen topics. roth-Municipal Corporations and Political Sub-divisions, to which I have referred seven topics.

I th-Domestic Relations, to which I have referred seven topics.

12th-Personal Rights, Relations and Disabilities, to which I have referred eighteen topics.

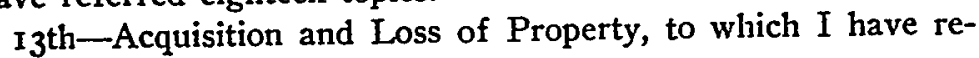
ferred five topics.

Ifth-Real Property, to which I have referred forty-one topics. $15^{\text {th }}$-Waters, to which I have referred three topics.

I6th-Personal Property, to which I have referred thirteen topics.

17th-Decedent's Estates, to which I have referred four topics. 18th-Trusts and Trustees, to which I have referred five topics. Igth-Contracts, to which I have referred fifty-two topics.

2oth-Particular Occupations, to which I have referred twentysix topics.

2Ist-Particular Associations and Corporations, to which I have referred twenty-three topics.

22nd-Debtor and Creditor, to which I have referred five topics.

23rd-Principles Affecting Property and Personal Rights and Contracts, to which I have referred four topics.

24 th-Torts, to which I have referred twenty topics.

On this basis it will be found I have accounted for 383 topics, considerably more than the total number of topics referable to substantive law, which I have already stated at 368 . This arises from the fact that, in the logical arrangement of subjects, some are necessarily referable to more than one general head, as, for instance, "Wharves," which, in respect to governmental control, is referable both to "Public Morals, Health and Safety," and to "Commerce, Transportation and Public Utilitics," and in respect to the mutual rights and duties of wharfingers and corporations and individuals making use of wharves, is referable to "Particular Occupations."

The business of dealing in intoxicating liquors, regarded as a particular occupation, is referable to that head; but, when regarded as a matter for governmental regulation for the protection of public morals, it is referable to another. And some topics, it may be remarked, seem as properly referable to either of two different heads. Contracts for the purchase or sale of real estate, 
which are treated under the title, "Vendor and Purchaser," may with equal propriety be referred to "Real Property" or "Contracts."

At this point I may refer to what has been designated by one of the great law publishers, the American System of Classification. In a recent publication this subject has been treated in an ingenious and striking way. The system is founded upon a formula which is said to give a correct and logical basis for the classification of all legal topics. This formula consists of the following definition of law :

"Law is the effort of society to protect PERSONS in their rights and relations, to guard them in their PROPERTY, enforce their CONTRACTS, hold them to their liability for their TORTS, punish their CRIMES by means of REMEDIES administered by the GOVERNMENT." From this definition we derive seven subdivisions of law, as follows:

I. Persons.

2. Property.

3. Contracts.

4. Torts.

5. Crimes.

6. Remedies.

7. Government.

Each of these grand clivisions is subdivided.

For example, the grand division "Persons" is allotted five subdivisions, viz.:

Ist-Matters relating to natural persons in general.

and-Particular classes of natural persons.

3 rd-Personal relations.

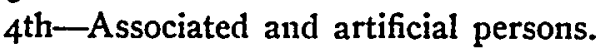

5th-Particular occupations.

Without going further in considering this arrangement, I may . say, briefly, that in its details it does not seem to me as logical as the grouping I have indicated. For instance, under the grand division "Persons" are placed, in the subdivision "Particular Occupations," the topics indicated by the latter title, including, among others, Druggists, Inn-keepers, Brokers, \&c.

Now, the cases under these topics principally consist of the application of the various contracts, which the law implies to regulate the dealings between one engaged in a particular trade or business and those for whom he performs services in the line of his trade or business. It seems to ine, therefore, that this group of subjects is more properly referable to "Contracts" than to "Per- 
sons." Many other cases under such topics as "Street Railways," which, in the publication I have mentioned, is assigned to the same group, involve governmental control of corporations engaged in a public service, to which are given the right of Eminent Domain, which I have referred to the group of "Commerce, Transportation and Public Utilities." On the whole, I think the use of the formula, although it gives rise to the magical number of seven in its grand divisions of the field of law, and satisfies the mental tendencies of those who regard the science of law as occult and are seeking for an "Abracadabra" to unlock its mysteries, is nevertheless a hindrance rather than an aid to a really rational and logical subdivision of the field of law and arrangement of the legal topics known to cligesters.

The student who has been applying himself to the treatises of elementary writers will, as I have already indicated, be apt to have his ideas of the relative importance of legal topics disturbed when he begins the use of the digest.

Upon turning from some voluminous work on real property to the digest, he will find the subject there disposed of in a half dozen pages. When he recovers from his surprise he will find some 44 topics representing subdivisions of that great subject. It would save him much time, annoyance and discouragement if he should familiarize himself with this important group of topics recognized by digesters under which the law of Real Property is to be found.

The same is true of Personal Property, which is not now regarded as a topic for treatment at all in the digest, either uncler that name or under Goods, Chattels or Biens, as our ancient friend Chief Baron Comyn treated it; but is to be found under the thirteen topics that I have assigned to it in the table to which I have referred, as well as under many of the topics I have assigned to the general category of contracts.

The subject of contracts has, indeed, some 300 pages allotted to it ; but there are more than 50 independent topics properly referable to that head, many of them of great importance. With these the students should also seek to acquire familiarity. Closely allied to these is the long list of particular occupations, each one of which illustrates the implied contract arising from the prosecution of that particular occupation and controlling the rights and duties of the parties. These many topics, when taken together, represent a vast field and make the subject of contracts the broadest of all to be found between the covers of the digest. 
Bailment, with but 18 pages in the digest, can clain over twenty topics properly referable to that head, among which I may mention Agistment, Auctions and Auctioneers, Banking, Boarding House Keepers, Carriers, Depositaries, Factors, Inn-keepers, Livery Stable Keepers, and as many others, which might swell the subject to proportions commensurate with the dignity which it has received at the hands of elementary writers.

Torts is dismissed with two pages in the digest, but is entitled to 20 topics that $I$ have assigned to it in my table.

Negligence has about sixty pages in the digest, but questions of negligence abound throughout the list of 26 topics referred to Particular Contracts and the 22 topics referred to Particular Associations and Corporations.

Another matter which should be brought to the attention of the student is that many cases referable to practice are to be found under topics which seem to represent substantive law. This is particularly true of questions relating to pleading, evidence and the correctness of instructions to the jury. Under many topics will be found a sub-title "Actions," and under this will be found the cases I have mentioned.

This is true of many of the particular occupations, contracts and associations and corporations. Many of these cases are of general application and quite as valuable when applied to other occupations, \&c., as to those under whose head they are found.

In conclusion, it may not be amiss to call your attention to the fact that the indices of current law reports may not be depended upon to enable one to find cases uncler the topics given in the digest.

When I first assumed the duties of Miscellaneous Reporter of the State of New York, I was puzzled to know upon what system the catch lines were formulated that precede the syllabi of the reported cases and usually serve to assign them to the topics under which they may be found in the index. The more I studied them the less able I was to apprehend the plan upon which they were formulated. I therefore wrote to the official reporters in the different states asking what systems they employed for the subject classification and indexing of cases. The replies that I received to my letters showed that no uniform system was in use, and one reporter candidly wrote me that it was a matter to which he had given very little attention. I adopted, however, as a standard for the Miscellaneous Reports the system employed in Abbott's Encyclopedic Digest of New York Reports; and the cases in the 
Miscellaneous Reports, beginning with Vol. 48, have been carefully assigned to the proper subjects as indicated by that system. The result is an index to each volume corresponding to the digest, and a facility of reference otherwise tunattainable. So far as I know, this plan has not been adopted by any other reporter; and catch lines and indices are alike unsatisfactory and misleading, for they guide one to topics under which a lawyer or student will often search in vain for the cases of which he is in quest.

To illustrate my meaning: On opening a recent volume of law reports the other day, I found a case, almost the first in the book, assigned by the catch lines to the subject "Evidence"; in turning to the index I found that the case was indexed under "Negligence"; but this case is not properly assignable to either of these heads and when digested will be placed under the topic, "Master and Servant." Another case, a little further on, assigned by the catch lines to the subject of "Pleading," indexed under the subject "Party," will be assigned in the Digest to the subject "Corporation." Another case, assigned by the catch lines to the subjeçt "Judgment" and indexed under "Railroad," will find its place in the Digest under the topic "Former Adjudication." It is probable that in the volume to which I refer less than one-half of the cases are assigned, either by the catch lines or the index, to the topics under which they will ultimately appear in the digest.

I am quite conscious of the fact that, after all I have said, the student is still under the necessity of familiarizing himself with the topics recognized by digesters and their scope. But it will aid him in the task to know the general nature of such topics and their relation to each other; and some of the hints I have given I hope may prove of future aid to those who may see these comments upon a subject in which $I$ have been much interested and which has seemed worthy of more attention than it has hitherto received.

Saratoga Falls, N. Y.

Charles C. Lester. 